\title{
EMPIRICAL ANALYSIS OF THE IMPACT OF BREXIT REFERENDUM AND POST-REFERENDUM EVENTS ON SELECTED STOCK EXCHANGE INDEXES
}

\section{Petar Kurecic, Filip Kokotovic}

\begin{abstract}
The paper studies the impact of political turbulence in the United Kingdom in 2016 and 2017 on selected relevant stock indexes. The empirical analysis consists of unit breakpoint tests. The potential points of structural break are determined based on an overview of occurrences of political instability from the Brexit referendum to the snap Parliamentary election of 2017. The paper concludes that the outcome of the referendum on Brexit caused a structural break that was visible in every stock index studied. On the other hand, the paper fails to find any evidence of a structural break caused by subsequent events, namely the decision to call the snap election or the outcome of the election itself. This implies that investors have accepted the UK decision to leave the EU and there was no further destabilization of the stock markets. It can be further concluded that the United Kingdom and the European Union need to address a deep political divide and find a way to coexist and mutually benefit in the period of negotiations and after the Brexit takes place.
\end{abstract}

Keywords: the United Kingdom (the UK), the European Union (the EU), Brexit referendum, stock market indexes, Chow's structural breakpoint test, economic and political implications.

JEL classification: $H 70, H 87, C 32$.

\section{INTRODUCTION}

The outcome of the Brexit referendum was a shocking event for the global political and economic system. Therefore, we have chosen to study its effects on the global equity markets primarily. It was an event that was not predicted, and as such, it caused unexpected, turbulent events on the markets. The main motive for studying this topic is observing the impact of the shock on the stock market to determine whether there was a structural change caused by Brexitrelated events. By viewing the strength of the immediate shock, it is possible to determine the statistical relevance of Brexit-related events on the stock market and determine whether these events had an impact on investor confidence. Additionally, the decision to call a snap Parliamentary election destabilized the economy further. Despite repeatedly given promises that there would be no early election, Madam Prime

Petar Kurecic, PhD

Associate Professor

University North, Department of Business and

Economics

E-mail: petar.kurecic@unin.hr

\section{Filip Kokotovic}

PhD student

Independent online learning examiner and

consultant

E-mail: filip.kokotovic@hotmail.com 
Minister Theresa May opted to call an election to secure a stronger Parliamentary majority as the upper hand in the negotiations on the terms of Brexit. Her gamble failed and she was forced into a weak coalition government that further weakens her position in the future negotiations on Brexit.

The macroeconomic data shows that the United Kingdom (hereafter: the UK) is more exposed and dependent on the European Union (hereafter: the EU) than vice versa. The key aspect is that the EU member states would find it much easier to find a substitute markets for their products and not a single EU member state would have an immediate negative impact as the UK would cave, were the negotiations to collapse and trade relations return to WTO regulation. Therefore, it is expected that the shock posed by the referendum on Brexit and the impact of the process of "Brexiting" i.e. "Brexitization" would affect the UK economy, its stock exchange, its currency and real estate market, respectively, among other things. The UK is expected to be more affected than the EU as a whole, and any of its national economies.

In the wake of the decision to leave the EU, the British pound (hereafter: the GBP) collapsed to its lowest level since the beginning of 1985, when Ronald Reagan was sworn in for a second term as US President (Gietel-Basten, 2016: 673). It is essential to understand how the markets respond to perceived political shocks, how quickly the markets recovered, as well as whether the impact of political events decreases or increases with time. The decision to vote for populist movements has become increasingly popular in numerous elections in Western countries. This problem was observed by Inglehart and Norris (2016), who believe that the key factor behind such decisions is a strong cultural backlash from demographics that fear progressive values, rather than economic reasons. The rationale behind such decisions is difficult to understand from an economic viewpoint, as the perceived regaining of sovereignty inflicted massive losses on the economy of the UK and on global equity markets, which lost more than two trillion US Dollars in value on June 24, 2016, upon news of the Brexit referendum result. This is the largest single-day loss in absolute value ever experienced on global equity markets and Davis (2016) estimates that it also drove global economic policy uncertainty to record highs. Currently, the stock market is constantly increasing in value and one of the rare instances where the entire market came to a halt was in the immediate aftermath of the Brexit referendum. Due to this reason, it is highly interesting to examine the position of investors and their uncertainty in the value of stock post-Brexit. The key research question is do investors continue to perceive
Brexit-related events as something that may impact their choices, or have they become accustomed to the political difficulties caused by Brexit.

Following the result of Brexit referendum, the London Stock Exchange's FTSE 100 immediately fell nearly $11 \%$ in dollar terms. The French and German stock markets lost $10 \%$ and $9 \%$, respectively. The very worst declines were experienced amongst the group of weaker, debt ridden EU countries: Portugal's stock market fell by $9 \%$, Ireland's by nearly $10 \%$, Italy's by $14.5 \%$, Greece's by $15.5 \%$ and Spain's by $14.4 \%$. UK markets observed the negative relationship between the value of British currency and the level of FTSE 100 Index (Burdekin et al., 2017: 1). The FTSE 250, which is made up of mostly mid-sized British companies, plummeted 7.2\% (Riley \& Long, 2016). The FTSE 100 lost $3.2 \%$ in a single day and The S\&P 500 fell 3.6\%, its biggest one-day drop since August, leaving it below where it finished 2015 (Mackenzie \& Platt, 2016).

The British financial sector, accounting for nearly one fifth of all global banking activity, is among those that have the most to lose with the UK leaving the Single Market (Miethe and Pothier, 2016: 364). In 2014, as regards the real economy, 44 per cent of the UK's exports and 53 per cent of imports were to and from the EU (Bank of England, 2015). The EU also accounts for a significant share of inflows and outflows of FDI, with 43.2 per cent of the UK overseas assets held in the EU and 46.4 per cent of assets held in the UK by overseas residents and businesses attributable to the EU (Jensen and Snaith, 2016: 1306). In 2015 inward FDI stock in the UK amounted to around $18.7 \%$ of inward FDI stock in the EU, while outward FDI stock for the UK stood for $16.5 \%$ of outward FDI stock for the EU (Pawlas, 2016: 60).

As the UK has business friendly environment, as reflected in global competitiveness surveys, and a relatively deregulated labour market, the EU membership is not the only driver of FDI. However, perhaps most important is the lure provided by the UK's large domestic economy. Nevertheless, FDI in manufacturing looks especially vulnerable to Brexit (Beck, 2016) ${ }^{1}$. A comparison of US FDI and foreign portfolio investment (FPI) across the EU countries illustrates the UK's significant role in this regard. In absolute numbers, US FPI into the UK was 1.5 times as large, and FDI three times as large, as those into Germany and France combined (Miethe and Pothier, 2016: 365).

In order to understand the impact of Brexit, the decision to call the early Parliamentary election, as well as other political implication, breakpoint tests are conducted. The results of these tests are then assessed from both a qualitative and quantitative perspective. Relevant implications are described for both the 
economy of the UK, as well as the trends in the global equity markets. Before performing an empirical analysis, the explanation is provided why this specific topic was chosen, through the literature review of references that point to the interdependence of the UK and other EU economies as well as the increased exposure of the UK economy after the referendum on Brexit.

\section{LITERATURE REVIEW}

As mentioned already the Brexit shock also sharply and immediately reflected on the exchange rate of the GBP. A huge intraday drop of the GBP against the USD was observed on 24 June 2016, in the wake of Britain's voting to leave the EU. The GBP lost as much as $11.1 \% 2$. The currency hit the bottom again after Theresa May's declaration of moving towards a "hard Brexit". USD/GBP exchange rate plumbed then by $6.1 \%$, reaching a record low level (Wielechowski and Czech, 2016: 175). Etuk and Amadi (2016) analysed, by using ARIMA methods, the realization of the daily GBP/USD exchange rate series from 17th March to 12th September, 2016. The intervention point is June 23,2016 , after which a sharp, statistically significant fall in the relative value of the GBP has occurred.

Krause et al. (2016) argue that the referendum in the UK created a high degree of uncertainty about possible consequences and that this could also be seen in financial markets in the run-up to the referendum. Negative consequences of exiting the EU are expected not only for the UK but also for the $\mathrm{EU}^{3}$. The results point to a strong depreciation of the GBP relative to the Euro or the Swiss franc, which might reflect the (expected) decline in the attractiveness of the UK as a financial centre and reduced demand for the GBP (in Belke et al., 2016: 8).

Rasmussen (2015) predicted that a post-Brexit UK would be vulnerable to market conditions imposed by the EU, as member states such as Germany and France would like to increase their share of financial services. Punitive externalities would likely be inflicted upon the UK, due to the increased fatigue of a number of member states caused by the UK's demanding behaviour. These predictions were correct; hence the migration of parts of the financial sector from the UK has started very soon after voting for Brexit. The EU has also profited from the fact that the sitting UK Conservative-led government is weaker than the previous one, according to Rasmussen (2015).

Some estimations claim that the cost of paying the EU to negotiate the terms of trade would be between 50 and 60 billion GBPs (Boffey et al., 2017). International Monetary Fund and British top economists' forecasts indicate negative impact of Brexit on future GDP growth rate. According to British government, Brexit would be one of 2019-2020 budget imbalances' reasons (Wielechowski and Czech, 2016: 179).

Besides the influence on stock markets, the exchange rate of the GBP, and other economic indicators, Brexit could also influence euro-denominated derivative trading activity, which could relocate to the euro area if the UK's financial institutions lose their financial passport rights. Some of the trading activity conducted by central counterparties will certainly relocate to countries within the euro area if the EU introduces location requirements on institutions engaging in euro denominated trades (Miethe and Pothier, 2016: 370). Ebell (2016) has compared market access under the current single market rules (i.e. an EEA-type agreement) and under a "normal" free trade agreement that focuses on tariffs. It concludes that the UK may experience a reduction of up to $45 \%$ in goods trade and up to $60 \%$ in services trade with the EU (Nicolaides and Roy, 2017: 103).

Raddant (2016) analysed the changes in the correlation of the stock indices (DAX30, FTSE100, FTSE MIB, IBEX 35, CAC 40) by estimating a multivariate GARCH model, which enabled the calculation of implied daily correlations between the indices and therefore overcame many statistical problems posed if correlations were calculated based on the raw data. The surprising outcome of the Brexit referendum came after the period of slight upward movement in the European stock market indices, recorded during the first half of 2016. After the Brexit referendum, stock prices dropped by around 10 percent and have by the end of 2016 only slowly returned to mid-June levels (Raddant, 2016: 5).

Belke et al. (2016) tried to predict the magnitude of the economic impact beyond the UK and which other countries might be affected. He determined that both the EU and the UK would face a detrimental impact on their economy, even in the medium term due to a spillover impact and the interconnectivity of the financial markets (Belke et al., 2016). The authors used both the Diebold and Yilmaz (2012) and the Hafner and Herwartz (2008) method to estimate the timevarying interactions between UK policy uncertainty and UK financial market volatilities (second statistical moment) to try to identify the direction of causality among them. The authors also used measures of the perceived probability of Brexit before the referendum, namely daily data released by Betfair and results of polls published by Bloomberg.

Sathyanarayana and Gargesha (2016) studied the reaction of Indian benchmark indices (Sensex and Nifty) to Brexit referendum, and whether there were 
any abnormal returns around the event date. The authors also investigated the Indian stock market's reaction reflect the market efficiency in semi strong form or not, by using event study methodology and GARCH model. They have found that there is a statistically significant link between Brexit-related events and the Sensex and Nifty fifty indices. The authors further observe that due to the negative impact of Brexit, foreign companies interested in doing business in the EU may move their centres from London to other EU member states (Sathyanarayana and Gargesha, 2016).

\section{THE EMPIRICAL ANALYSIS OF BREXIT'S IMPACT ON STOCK INDICES}

\subsection{Data and methods}

The decision of the UK to leave the EU presented a challenge for the very existence of the world's largest economic integration, thus increasing the political risk and adverse impact on the international economy. This hypothesis is based on the simple fact that all modern currencies are fiat currencies that, since US President Nixon's 1971 abolishment of the gold window, are based on the perception of value rather than on value itself. Similarly, modern stock indexes are based on political stability and investor's confidence. One hypothesis would be that all stock markets have the same negative impact, while an alternative hypothesis could be derived based on the research by Carrère and Schiff (2006), whose paper focuses on the concept of geographical relevance of trade, as well as the so called "gravity model". The initial hypothesis, if we accept the feasibility of the gravity models for stock markets, would be that the strongest impact would be on the European stock market, while American, Asian, and other stock markets would not have such adverse responses. In order to test this theory we have implemented the approach based on a version of Chow's (1960) structural breakpoint test, explained in more detail in what follows.

The key aspects of the empirical methodology will be to examine the impact of the decision of the British electorate to opt out of the EU on the 24th of June of 2016, the decision of the UK Parliament to pass the EU Notification of Withdrawal Act on the 1st of February, 2017, as well as the decision by the sitting Madam Prime Minister to invoke the article 50 of the Lisbon Treaty, which was delivered on the 29th of March, 2017, with a two year transition period, after which the "hard Brexit" would be affective. This part of the empirical analysis will allow us to determine the immediate impact of the referendum result and the decision to formally start the procedure of exiting the EU. To understand the impact of the snap Parliamentary election, two dates are considered for structural brakes. The first date is the 18th of April, 2017, when the Madam Prime Minister announced her decision to hold a Parliamentary election in order to strengthen the negotiating position of the UK in Brexit negotiations and ensure stability ${ }^{4}$. The second date is that of the 8th of June of 2017, when the Parliamentary election took place and the Labour Party managed to achieve a far better result than most political analysts expected.

In order to conduct our analysis, we have extracted the open value for 12 different stock indexes from May 10th 2016 to July 26th 2017 (Financial Times, 2017). The stock indexes are identified and shortly presented in Table 1. Movement of the log transformed three key indices in the observed period, as well as descriptive statistics for all of the variables used, are presented in the Appendix 1 and 2, respectively.

An empirical analysis is conducted by using a version of Chow's (1960) test for a structural break. This is done by implementing a standard Ordinary Least Squares (OLS) regression with a respective stock index as the dependent variable and the lag of the stock index as the explanatory variable. In order to ensure that the error term follows a normal distribution, the values of the studied stock indexes were transformed into their natural logarithms. As having only one lag may have a low predictability value, more lags can be included to enhance the predictability value of the regression model.

Thus, the general equation is as follows:

$\ln \left(S I_{t}\right)=\alpha_{0}+\ln \left(S I_{t-1}\right)+\cdots+\ln \left(S I_{t-n}\right)+\varepsilon_{t}$

In equation (1), SI is the stock index. We also included a constant, error term, as well as a sufficient $(n)$ number of lags to ensure that the model will have a statistically significant predictability value. The calculations were conducted by using the Gnu Regression, Econometrics and Time-series Library (GRETL) software.

At this point, it is important to acknowledge certain methodological and data limitations. One of the limitations concerning the methodology is the arbitrary nature of the selection of the period. It is our belief that the past year is a relevant time frame to examine the impact of the Brexit referendum. Nevertheless, the shorter the time period used, the larger the chance that the Chow breakpoint test would yield a statistically significant result. The methodology of measuring the various stock indexes used in this study should not have any significance for the final results, although 
Table 1: Presentation and Description of Stock Indexes

\begin{tabular}{|c|c|c|c|}
\hline Name of Index & $\begin{array}{l}\text { Abbreviation } \\
\text { used }\end{array}$ & Short Description & Relevance \\
\hline $\begin{array}{l}\text { Standard \& Poor's } \\
500\end{array}$ & S\&P 500 & $\begin{array}{l}\text { An equity index that represents the strength of } \\
\text { over } 80 \% \text { of the American economy by represent- } \\
\text { ing } 500 \text { of its companies. }\end{array}$ & $\begin{array}{l}\text { Stability index of the } \\
\text { American stock market }\end{array}$ \\
\hline $\begin{array}{l}\text { Dow Jones } \\
\text { Industrial Average }\end{array}$ & Dow & $\begin{array}{l}\text { A strength index of American industries that is } \\
\text { calculated from } 30 \text { relevant American companies. }\end{array}$ & $\begin{array}{l}\text { Stability index of the } \\
\text { American stock market }\end{array}$ \\
\hline $\begin{array}{l}\text { NASDAQ } \\
\text { Composite }\end{array}$ & NASDAQ & $\begin{array}{c}\text { A stock market index of the common stocks listed } \\
\text { on the NASDAQ stock market. }\end{array}$ & $\begin{array}{l}\text { Stability index of the } \\
\text { American stock market }\end{array}$ \\
\hline $\begin{array}{l}\text { Financial Times } \\
\text { Stock Exchange } \\
100 \text { Index }\end{array}$ & FTSE 100 & $\begin{array}{c}\text { A share index of the strength of the } 100 \text { companies } \\
\text { that are highest on the London Stock Exchange } \\
\text { based on market capitalization. }\end{array}$ & $\begin{array}{l}\text { Stability index of the British } \\
\text { stock market }\end{array}$ \\
\hline $\begin{array}{l}\text { Deutscher } \\
\text { Aktienindex }\end{array}$ & DAX & $\begin{array}{l}\text { A stock market index that consists of the } 30 \text { largest } \\
\text { companies of the Frankfurt Stock Exchange based } \\
\text { on market capitalization and order book volume. }\end{array}$ & $\begin{array}{l}\text { Stability index of the } \\
\text { German stock market }\end{array}$ \\
\hline $\begin{array}{l}\text { Cotation Assistée } \\
\text { en Continu }\end{array}$ & CAC & $\begin{array}{l}\text { A capitalization-weighted measure of the } 40 \text { most } \\
\text { significant companies on the Euronext Paris. }\end{array}$ & $\begin{array}{l}\text { Stability index of the French } \\
\text { stock market }\end{array}$ \\
\hline $\begin{array}{l}\text { Financial Times } \\
\text { Stock Exchange } \\
\text { Eurofirst } 300\end{array}$ & Eurofirst & $\begin{array}{c}\text { An index that consists of the } 300 \text { largest compa- } \\
\text { nies ranked by market capitalization in the FTSE } \\
\text { Developed Europe Index. }\end{array}$ & $\begin{array}{l}\text { Stability index of the } \\
\text { European stock market }\end{array}$ \\
\hline $\begin{array}{l}\text { Johannesburg } \\
\text { Stock Exchange All } \\
\text { Share Index }\end{array}$ & JSE & $\begin{array}{l}\text { An index that consists of approximately } 160 \text { com- } \\
\text { panies that are traded on the Johannesburg Stock } \\
\text { Exchange. }\end{array}$ & $\begin{array}{l}\text { Stability index of the South } \\
\text { African stock market }\end{array}$ \\
\hline $\begin{array}{l}\text { Nikkei Stock } \\
\text { Average }\end{array}$ & Nikkei & $\begin{array}{l}\text { A price-weighted index that consists of the } 225 \\
\text { highest ranked companies on the Tokyo Stock } \\
\text { Exchange. }\end{array}$ & $\begin{array}{l}\text { Stability index of the } \\
\text { Japanese stock market }\end{array}$ \\
\hline Hang Seng Index & Hang Seng & $\begin{array}{l}\text { A market capitalization-weighted stock market } \\
\text { index that measures the performance of } 50 \text { com- } \\
\text { panies on the Hong Kong Stock Exchange. }\end{array}$ & $\begin{array}{l}\text { Stability index of the Hong } \\
\text { Kong Stock Exchange }\end{array}$ \\
\hline $\begin{array}{l}\text { Shanghai Stock } \\
\text { Exchange } \\
\text { Composite Index }\end{array}$ & Shanghai & $\begin{array}{l}\text { An index that measures the value of exchange on } \\
\text { the Shanghai Stock Exchange, measuring the value } \\
\text { in comparison with the launch values. }\end{array}$ & $\begin{array}{l}\text { Stability index of the } \\
\text { Chinese stock market }\end{array}$ \\
\hline $\begin{array}{l}\text { Russia Trading } \\
\text { System Index }\end{array}$ & RTS & $\begin{array}{l}\text { A capitalization-weighted index of } 50 \text { Russian } \\
\text { stocks traded on the Moscow Stock Exchange. }\end{array}$ & $\begin{array}{l}\text { Stability index of the Russian } \\
\text { stock market }\end{array}$ \\
\hline
\end{tabular}

Source: Financial Times, https://www.ft.com/markets (Accessed May 7, July 29, 2017).

we fully acknowledge that different methodological approaches are used to calculate a vast majority of these indexes. Another problem with the methodology is somewhat arbitrary nature of the selection of the events that may have caused the largest economic shock. This was determined by the most relevant political events for the further development of the Brexit process.

The initial discussion focuses on our expectations vis-à-vis the various stock indexes used. To summarize the key ideas identified in the methodology section, we identified two basic hypotheses:

- Hypothesis 1: There is a more pronounced statistically significant structural break in markets that are geographically closer to the EU and the UK itself.

- Hypothesis 2: Due to the interconnected nature of the global economy, similar values concerning Chow's structural breakpoint test are expected worldwide.

\subsection{Results}

The results of Chow's structural breakpoint test are presented in Table 2, allowing us to develop the discussion.

Besides very limited evidence of a gravity impact, 
Table 2: Results for Chow's Structural Breakpoint Test

\begin{tabular}{|c|c|c|c|}
\hline Index & $\begin{array}{l}\text { Structural break on the 24th } \\
\text { of June, } 2016\end{array}$ & $\begin{array}{l}\text { Structural break on the 1st } \\
\text { of February, } 2017\end{array}$ & $\begin{array}{l}\text { Structural break on the 29th } \\
\text { of March, } 2017\end{array}$ \\
\hline$S \& P 500$ & $\begin{array}{c}6.8504^{* * *} \\
(0.0013)\end{array}$ & $\begin{array}{c}0.4895 \\
(0.6135)\end{array}$ & $\begin{array}{c}0.6212 \\
(0.5381)\end{array}$ \\
\hline Dow & $\begin{array}{l}13.077^{* * *} \\
(0.0000)\end{array}$ & $\begin{array}{c}0.5349 \\
(0.5864)\end{array}$ & $\begin{array}{c}0.6591 \\
(0.5182)\end{array}$ \\
\hline NASDAQ & $\begin{array}{l}3.8235^{* *} \\
(0.0232)\end{array}$ & $\begin{array}{c}0.4326 \\
(0.6493)\end{array}$ & $\begin{array}{c}2.0717 \\
(0.1282)\end{array}$ \\
\hline FTSE 100 & $\begin{array}{l}4.565^{* *} \\
(0.0113)\end{array}$ & $\begin{array}{c}0.8721 \\
(0.4194)\end{array}$ & $\begin{array}{c}1.425 \\
(0.2424)\end{array}$ \\
\hline$D A X$ & $\begin{array}{c}10.769^{* * *} \\
(0.0000)\end{array}$ & $\begin{array}{c}1.498 \\
(0.2255)\end{array}$ & $\begin{array}{c}1.139 \\
(0.3217)\end{array}$ \\
\hline$C A C$ & $\begin{array}{l}7.7124^{* * *} \\
(0.0006)\end{array}$ & $\begin{array}{c}1.2177 \\
(0.2977)\end{array}$ & $\begin{array}{c}1.9602 \\
(0.1431)\end{array}$ \\
\hline Eurofirst & $\begin{array}{l}7.0399 * * * \\
(0.0011)\end{array}$ & $\begin{array}{c}1.7411 \\
(0.1774)\end{array}$ & $\begin{array}{c}1.6801 \\
(0.1884)\end{array}$ \\
\hline$J S E$ & $\begin{array}{c}1.6273 \\
(0.1986)\end{array}$ & $\begin{array}{c}0.3965 \\
(0.6731)\end{array}$ & $\begin{array}{c}0.2875 \\
(0.7504)\end{array}$ \\
\hline Nikkei & $\begin{array}{c}13.2713^{* * *} \\
(0.0000)\end{array}$ & $\begin{array}{c}1.7386 \\
(0.1780) \\
\end{array}$ & $\begin{array}{c}1.7172 \\
(0.1818)\end{array}$ \\
\hline Hang Seng & $\begin{array}{c}1.8417 \\
(0.1608)\end{array}$ & $\begin{array}{c}0.4755 \\
(0.6221)\end{array}$ & $\begin{array}{c}0.7971 \\
(0.4518)\end{array}$ \\
\hline Shanghai & $\begin{array}{l}3.5057^{* *} \\
(0.0316)\end{array}$ & $\begin{array}{c}2.0036 \\
(0.1371)\end{array}$ & $\begin{array}{l}3.078^{* *} \\
(0.0479)\end{array}$ \\
\hline$R T S$ & $\begin{array}{l}4.4441^{* *} \\
(0.00127)\end{array}$ & $\begin{array}{l}3.518^{* *} \\
(0.0311)\end{array}$ & $\begin{array}{l}2.8107^{*} \\
(0.0621)\end{array}$ \\
\hline
\end{tabular}

Source: Authors' calculations based on GRETL output.

Note: Values in the parentheses represent the $p$ value. ${ }^{*},{ }^{* *}$, and ${ }^{* * *}$ indicate statistical significance at the respective $0.1,0.05$, and 0.01 levels of significance.

minor discrepancies in the general trends within the observed indexes are found. It should be noted that the decision of the British electorate to opt out of the EU caused a structural break in nearly all of the observed indexes when the results of the Brexit referendum became known. The exceptions are the JSE and the Hang Seng index, which did not display evidence of a structural break, caused by the announcement of the referendum result. Both of these, relatively smaller indexes, were clearly not as impacted as the larger indexes that highly depend upon the stability of the international market. The majority of the other indexes conform to the hypothesis that anticipated similar results.

Conversely, in the aftermath of the referendum, even the FTSE index was not impacted by the major decisions of the UK to formally leave the EU on the $1^{\text {st }}$ of February 2017. This is most likely caused by the fact that investors have already accepted the fact that the UK would leave the EU and there was no further impact or destabilization of the market caused by what they perceived as merely a formality.

There is further evidence for the theory that suggests a larger level of integration of the global economy. While no evidence of a structural break in neither the FTSE nor the major European indexes was found on the 1st of February and the 29th of March 2017, respectively, there was evidence of such a break in the Chinese and Russian stock exchanges. In the aftermath of the referendum, it is clear that investors on a global scale have gotten used to the Brexit phenomenon and that there is no impact of Brexit-related political instability on investor confidence. The structural breaks on the 1st of February and on the 29th of March in the case of the Chinese and Russian stock market exchanges can more likely be explained by a nine-year-high level of inflation in China in February 2017 and the strong protests in Russia in March 2017, respectively.

The decision of Madam Prime Minister May to call 
a snap Parliamentary election did not cause shock to global equity markets. There is no evidence of such a trend at the $5 \%$ level of statistical significance in none of the observed indexes, which is why the results are not reported in the above table. While it is known that the value of the GBP rose slightly after the decision to call the election was announced, the decrease of the Conservative Party's popularity and the outcome of the election, which required the previously ruling Party to form a coalition government with a very slim majority did not help in stabilizing the economy. The fact that the decision of the Conservative Party to call a snap Parliamentary election did not cause structural breaks in the global equity markets proves that the investors in the UK, domestic and foreign, have grown accustomed to occurrences of political instability, or at least unusual political decision-making in the UK. Furthermore, it seems increasingly likely that avoiding a "hard Brexit" might become a necessity. The facts that the Conservative Party has lost its majority and that the amendment was passed in the Parliament in December 2017, obliging the Parliament to take a vote on the final decision on Brexit deal, following a rebellion by backbench Conservative MPs (Price and Payne, 2017), are seen as major defeats of May's government.

\section{CONCLUSION}

The impact of the Brexit referendum and the decisions of the UK government that followed it have brought significant negative effects to the UK economy, and jeopardized the position of the UK citizens working and living in the EU countries, and vice versa. Due to many uncertainties about the epilogue of the Brexit process, it cannot be predicted how long will it take for the UK and for the rest of the EU to fully adapt to the situation and accommodate their newly established interests. It is clear that there is a strong negative impact of Brexit and other political events on the global equity markets. Without a clear negotiating strategy and without a sure transitional deal, the economy of the UK could struggle and attempt to use unrealistic alternatives, in the attempts to soothe the mood of the electorate. Perhaps the best example of such an alternative is the idea of turning the UK into a tax haven. There are numerous downsides to such an idea. The electorate has gotten accustomed to the standard of labour rights protected by the EU regulation. The transformation of the UK into a tax haven would require a decrease in the short-term government spending. It is almost certain that part of that spending would have to be cut from entitlement programs that would only make Brexit less popular
(Murphy, 2016). Based on the results of this empirical analysis, it can also be concluded that investors seem to quickly adapt to occurrences of political uncertainty. Therefore, occurrences of such kind do not produce long-lasting structural breaks in the observed equity markets. The persisting strong and at certain times negative rhetoric coming from the UK and the EU, respectively, seems to be of little importance to the value of equity markets that have adapted, treating it as "business as usual".

\section{REFERENCES}

Bank of England. 2015. EU membership and the Bank of England, Bank of England Report, London: Bank of England, http://www.bankofengland.co.uk/publications/Documents/speeches/2015/euboe211015.pdf Accessed December 22, 2017.

Beck, M. 2016. Brexit and FDI, in: Assessing the Economic Implications of Brexit. Oxford Economics Research Program, 26-30, http://www.oxfordeconomics.com/ brexit Accessed October 25, 2017.

Belke, A., Dubova, I. and T. Osowski. 2016. Policy Uncertainty and International Financial Markets: The Case of Brexit. CEPS Working Document, 429 1-36.

Boffey, D., Rankin, J. and A. Asthana. 2017. UK could pay E50bn Brexit divorce bill after bowing to EU pressure. The Guardian, November 29, https://www.theguardian.com/ politics/2017/nov/28/uk-and-eu-agree-brexit-divorcebill-that-could-reach-57bn Accessed December 23, 2017.

Burdekin, R.C.K., Hughson, E. and J. Gu. 2017. A first look at Brexit and global equity markets. Applied Economics Letters, 25 (2), 1-5.

Carrère, C. and M. Schiff. 2006. On the Geography of Trade: Distance is Alive and Well. Revue Économique, 56, 1249-1274.

Chow, G.C. 1960. Test of Equality between Sets of Coefficients in two Linear Regressions. Econometrica, 28 (3), 591-605.

Davis, S.J. 2016. An Index of Global Economic Policy Uncertainty. NBER Working Paper, 21633 Diebold, F.X. and K. Yilmaz. (2012. Better to give than to receive: predictive directional measurement of volatility spillovers. International Journal of Forecasting 28 (1), 57-66.

Ebell, M. 2016. Assessing the Impact of Trade Agreements on Trade. National Institute Economic Review, 238 (1), R31-R42.

Etuk, E.H. and E.H. Amadi. 2016. Intervention Analysis of Daily GBP-USD Exchange Rates Occasioned by BREXIT. International Journal of Management, Accounting and Economics, 3 (12), 797-805.

Financial Times. 2017. Historical Value of Market Indexes, https://www.ft.com/markets Accessed May 7, 2017. 
Gietel-Basten, S. 2016. Why Brexit? The Toxic Mix of Immigration and Austerity. Population and Development Review, 42 (4), 673-680.

Global Competitiveness Report, World Economic Forum, 2015-16, http://reports.weforum.org/global-competitivenessreport-2015-2016/competitiveness-rankings/ Accessed October 26, 2017.

Hafner, C.M. and H. Herwartz. 2008. Testing for causality in variance using multivariate $\mathrm{GARCH}$ models. Annales d'Économie et de Statistique, 89, 215-241.

Inglehart, R. and P. Norris. 2016. Trump, Brexit, and the Rise of Populism: Economic Have-Nots and Cultural Backlash. HKS Working Paper, No. RWP16-026, 2016. Available at: https://papers.ssrn.com/sol3/papers.cfm?abstract id=2818659 Accessed July 28, 2017.

International Monetary Fund. 2016. Uncertainty in the aftermath of the U.K. referendum. World Economic Outlook Update, International Monetary Fund, Washington, D.C., 19 July.

Jensen, M.D. and H. Snaith. 2016. When politics prevails: the political economy of a Brexit. Journal of European Public Policy, 23 (9), 1302-1310.

Mackenzie, M. and E. Platt. 2016. How Global Markets Are Reacting to UK's Brexit Vote. Available at: http:// www.ft.com/cms/s/2/50436fde-39bb-11e6-9a0582a9b15a8ee7.html\#axzz4CXgCOomh Accessed December 24, 2017.

Miethe, J. and D. Pothier. 2016. Brexit: What's at stake for the financial sector? DIW Economic Bulletin, 31, 364-372.

Murphy, R. 2017. Why becoming a tax haven would be bad news for Britain. The Guardian, March 22. Available at: https://www.theguardian.com/world/2017/mar/22/taxhaven-theresa-may-bad-news-britain-brexit Accessed July 29, 2017.

\section{(Endnotes)}

1 In 2015, the World Bank ranked the UK as the sixth best country in the world for ease of doing business, ahead of every other EU member apart from Denmark. According to the 2015-16 Global Competitiveness Report, the UK sat in tenth place out of 140 countries in a measure of global competiveness. For more details, see Beck (2016).

2 Raddant (2016: 5) gives the following data: In the medium run the pound lost $8 \%$ of its value against the Euro and $10 \%$ against the US Dollar while the Euro depreciated against the US Dollar by $3.5 \%$.
Nicolaides, P.A. and T. Roy. 2017. Brexit and Trade: Between Facts and Irrelevance. Intereconomics, 2, 100-106.

Pawlas, I. 2016. Brexit as a Challenge for the European Union. Horyzonty Polityki, 20, 57-76.

Price, R. and A. Payne. 2017. MPs will get a meaningful vote on the final Brexit deal in a major defeat for May's government. Business Insider UK, December 13. Available at: http://uk.businessinsider.com/brexit-amendment7-meaningful-vote-final-deal-2017-12 Accessed December 26, 2017.

Quaye, I., Yinping, M., Abudu, B. and R. Agyare. 2016. Review of Stock Markets' Reaction to New Events: Evidence from Brexit. Journal of Financial Risk Management, 5, 281-314.

Raddant, M. 2016. The Response of European Stock Markets to the Brexit. Kiel Policy Brief, 100 1-11. Available at: https://www.ifw-kiel.de/wirtschaftspolitik/zentrumwirtschaftspolitik/kiel-policy-brief/kpb-2016/kpb 100. pdf Accessed December 24, 2017.

Riley, C. and H. Long. 2016. Biggest Losers: "Brexit" Is Already Hitting These Companies. Available at: http://money.cnn. com/2016/06/24/investing/brexit-uk-companies/index. html?iid=hp-topleaddom Accessed December 24, 2017.

Sathyanarayana S. and S. Gargesha. 2016. Impact of BREXIT Referendum on Indian Stock Market. International Journal of Management \& Social Sciences, 5 (1), 104-121.

UK Office for National Statistics. 2017. https://www.ons.gov. uk/ Accessed May 25, 2017.

Wielechowski, M. and K. Czech. 2016. Brexit Related Uncertainty for United Kingdom Economy. Oeconomia, 15 (4), 171-181.

World Bank Doing Business 2015 rankings, http://www.doingbusiness.org/rankings Accessed October 26, 2017.

Yan, S. 2016. Global Banks Hammered by U.K. Vote. Available at: http://money.cnn.com/2016/06/24/investing/brexitbank-impact/index.html Accessed December 24, 2017.

3 The EU economies are also expected to be net losers of Brexit. Based on financial and trading linkages, Ireland ( -0.6 to $-2 \%$ of GDP), the Netherlands $(-0.3 \%$ to $-0.7 \%$ of GDP) and Belgium ( -0.25 to $-0.65 \%$ of GDP) are the most affected countries. Other member states should fall between 0.2 to $0.5 \%$ below baseline (IMF, 2016).

4 This remains as an unclear reason for calling the election, because the only party in Parliament that openly opposed Brexit was the Liberal Democrat Party. The party held only eight seats in Parliament and it is probable that Madam Prime Minister May expected she could strengthen rather "thin" majority that included the Conservative legislators that backed Remain during the referendum. 
Figure A1: Movement of log transformed FTSE index in the observed period

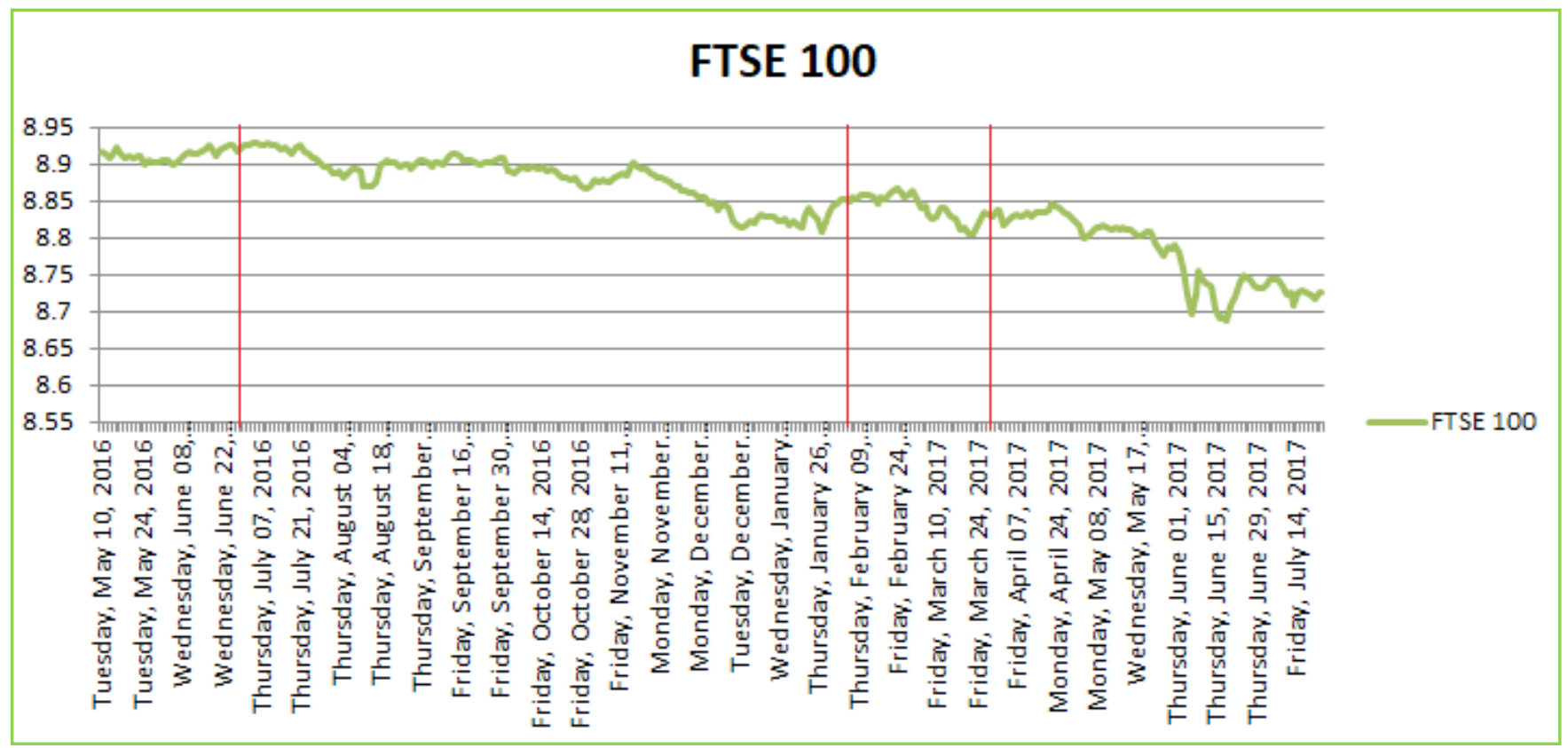

Note: Vertical lines denote the potential breakpoint dates identified by the qualitative analysis.

Source: Financial Times, 2017

Figure A2: Movement of log transformed Dow Jones index in the observed period

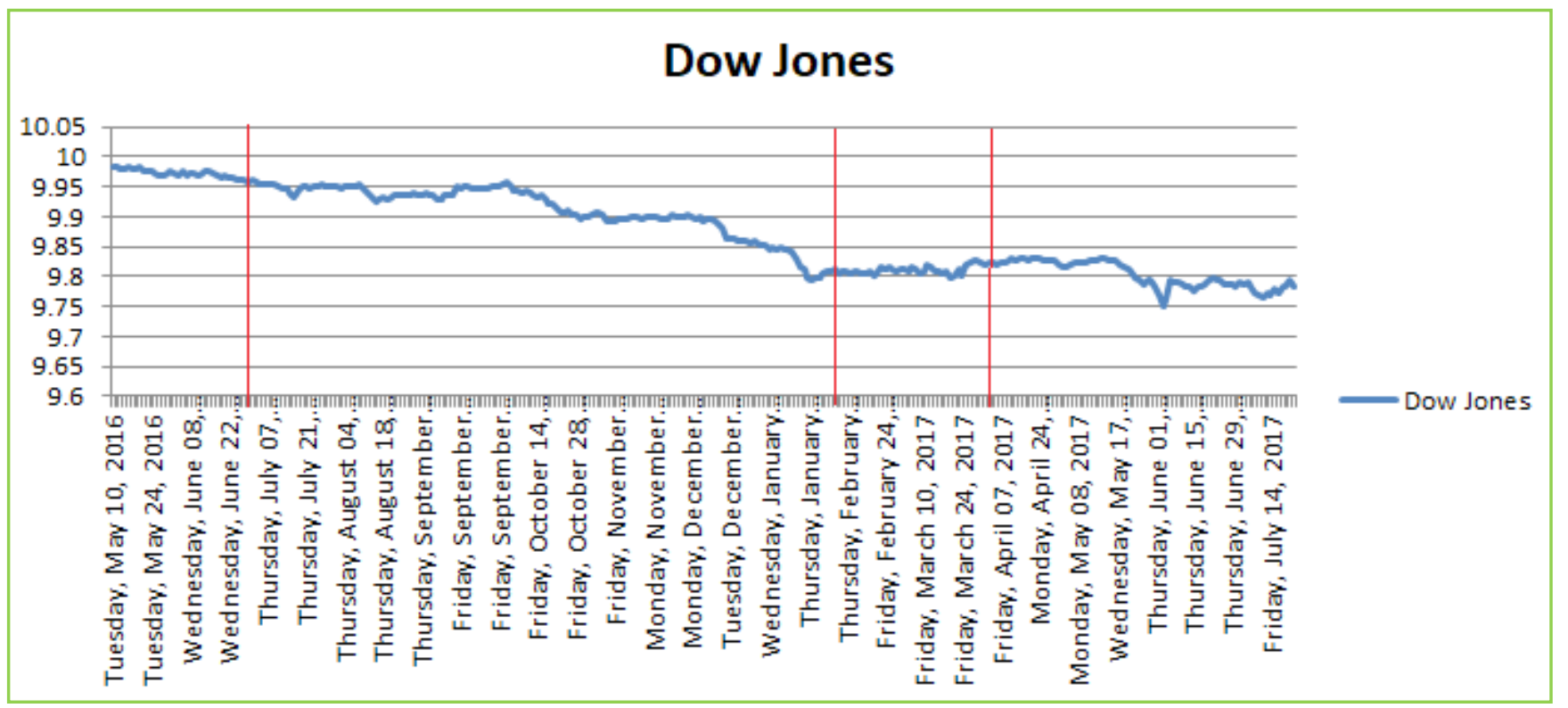

Note: Vertical lines denote the potential breakpoint dates identified by the qualitative analysis.

Source: Financial Times, 2017 
Figure A3: Movement of log transformed S\&P index in the observed period

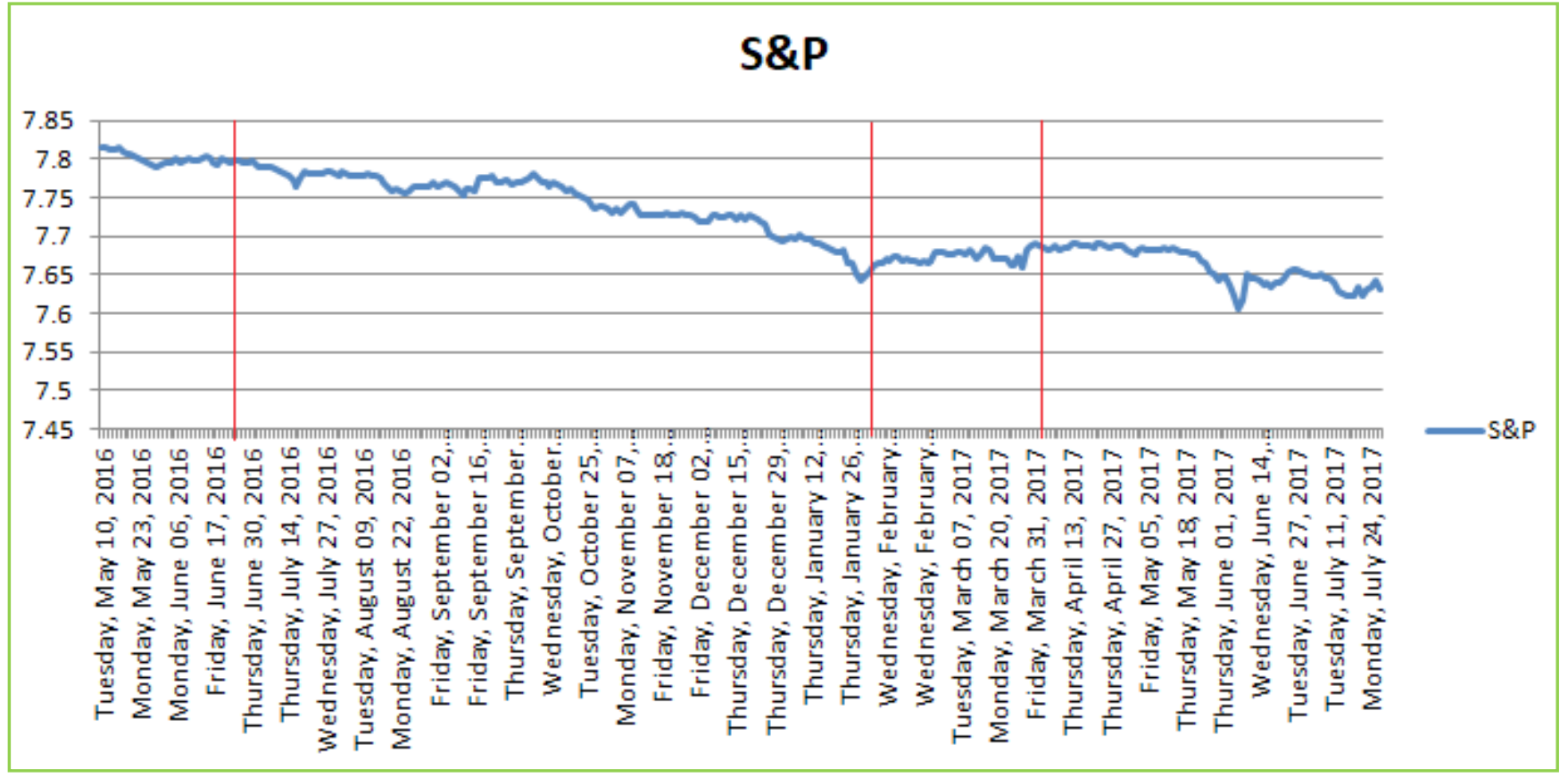

Note: Vertical lines denote the potential breakpoint dates identified by the qualitative analysis.

Source: Financial Times, 2017

Appendix 2

Table A1: Summary statistics of variables for breakpoint tests

\begin{tabular}{|c|c|c|c|c|c|c|c|c|}
\hline & Mean & Median & Minimum & Maximum & Std. Dev. & C.V. & Skewness & Ex. kurtosis \\
\hline S\&P 500 & 2254.9 & 2258.8 & 2006.7 & 2480 & 124.5 & 0.055201 & 0.087 & -1.32 \\
\hline Dow & 19519 & 19795 & 17191 & 21690 & 1328 & 0.068 & 0.05 & -1.53 \\
\hline FTSE 100 & 6993 & 7037 & 5923 & 7457 & 401.7 & 0.057 & -0.76 & -0.17 \\
\hline DAX & 11249 & 11267 & 9237 & 12938 & 997.5 & 0.089 & 0.038 & -1.31 \\
\hline CAC & 4749 & 4768 & 4073 & 5442 & 365 & 0.076 & 0.21 & -1.23 \\
\hline Eurofirst & 1412.6 & 1412 & 1223 & 1557 & 82.3 & 0.058 & 0.135 & -1.31 \\
\hline JSE & 52263 & 4769 & 4918 & 55074 & 1198 & 0.023 & -0.19 & -0.5 \\
\hline Nikkei & 18157 & 1412 & 15095 & 20261 & 1469 & 0.081 & -0.21 & -1.44 \\
\hline Hang Seng & 23279 & 23239 & 19632 & 27003 & 1715 & 0.074 & -0.065 & -0.48 \\
\hline Shanghai & 3101 & 3116 & 2793 & 3286 & 119.6 & 0.039 & -0.73 & -0.05 \\
\hline RTS & 1032 & 1032 & 881 & 1192 & 84.9 & 0.082 & 0.21 & -1.19 \\
\hline NASDAQ & 5522 & $5436+7$ & 4644 & 6426 & 466.8 & 0.08 & 0.15 & -1.09 \\
\hline
\end{tabular}

Source: Authors' calculations 